\title{
Permaculture in the margins: realizing Central European regeneration
}

\author{
A. June Brawner ${ }^{1}$ \\ University of Georgia, USA
}

\begin{abstract}
As the adverse effects of intensive, high-input food production are made increasingly obvious, alternatives are ubiquitous; these localized alternatives can also be a model for resistance, creating space for the negotiation of 'progress', particularly in marginal and peripheral places. Using an international permaculture site in rural Bulgaria as a case study, this article explores the permaculture 'web of mutually beneficial relationships' that are both social and ecological, informing a model for sustainable livelihoods in a transformational time. Introducing the work of permaculture co-founder Bill Mollison to the rural postsocialist transition studies of Stahl, Cellarius, and others, permaculture inspires progress re-defined through subsistence and creative response to change.
\end{abstract}

Keywords: permaculture, food systems, sustainable development, Postsocialist Europe

\section{Résumé}

Comme les effets néfastes de l'agriculture à forte intensité d'intrants externes sont faites de plus en plus évidente, les alternatives sont omniprésents; ces alternatives localisées peuvent également être un modèle pour la résistance, créant un espace pour la négociation de «progrès», en particulier dans des endroits marginaux et périphérales. En utilisant un site international de permaculture en Bulgarie rural comme une étude de cas, cet article explore le «réseau de relations mutuellement bénéfiques» de permaculture à la fois sociale et écologique, informant un modèle pour les moyens de subsistance durables. Le travail du cofondateur Bill Mollison permaculture est introduit aux côtés des études de transition post-socialistes rurales de Stahl, Cellarius, et d'autres. Permaculture inspire progrès, re-défini par l'agriculture de subsistance et des réponses créatives dans un temps de transformation.

Mots-clés: permaculture, les systèmes alimentaires, développement durable, l'Europe postsocialiste

\section{Resumen}

Los efectos adversos del sistema alimentaria convencional ha motivado la creación de muchas alternativas agrícolas locales. Estas alternativas sirven como modelos de resistencia, abriendo espacios para la negociación del concepto de 'progreso', en particular en lugares marginales de la periferia. Basándose en el estudio de un sitio internacional de permacultura en la Bulgaria rural, este articulo analiza 'la red de relaciones mutuas y benéficas' que son a la vez sociales y ecológicas, para contribuir a un modelo para modos de vivir sustentables en un momento histórica de transformación. El articulo introduce el trabajo del cofundador de la permacultura, Bill Mollison, a los estudios de la transición del mundo rural pos-socialista hechos por Stahl, Cellarius y otros, para inspirar una redefinición del progreso que integra la subsistencia y la respuesta creativa al cambio.

Palabras Clave: permacultura; sistemas alimentarias; desarrollo sustentable, Europa pos-socialista.

\footnotetext{
${ }^{1}$ A. June Brawner, PhD student, Department of Anthropology and MS student, Department of Crop and Soil Sciences, University of Georgia, USA. Email: brawner "at" uga.edu. Thankyou to the editors and referees. This is the fifth article in James R. Veteto and Joshua Lockyer (eds.) 2015. "Towards a political ecology of applied anthropology", Special Section of the Journal of Political Ecology 22: 357-465.
} 


\section{Introduction}

I first encountered permaculture in action during fieldwork in Shipka, a small town in the Balkan mountains of Central Bulgaria in the spring of 2011. Here, permaculture was explained to me by Damyan ${ }^{2}$, a young Bulgarian of Canadian birth and a permaculture teacher, as a philosophy of design that emphasizes the modeling of edible gardens after observable ecological processes in order to foster regenerative and sustainable agricultural systems. According to Damyan, permaculture might be practiced in pots in the windowsills of a high rise urban apartment or on subsistence farms in the valleys of the Balkan Mountains. While there may be as many definitions of permaculture as there are practitioners, it is a uniting framework of philosophical and ecological principles that lends continuity to permaculture as a social-ecological, and ultimately agricultural, paradigm. Primarily, through the positioning of the gardener as an agent of nature, permaculture aims to maximize agricultural production while minimizing input and harnessing the efficiency of time-tested interspecies relationships recognizable in dynamic social-ecological systems.

Perhaps because the reach of permaculture fails to fall solidly within any one discipline, few academic works have given this 'philosophy of design' serious attention. However, it is worth noting that the deficit of anthropological (and other academic) engagement with permaculture described by Veteto and Lockyer (2008) has not prevented the influence of anthropology on the permaculture worldview. In addition to anthropology's more recent and overt engagement with permaculture (e.g. Lockyer and Veteto 2013), a number of anthropological contributions have informed permaculture from its conception. Perhaps the most prevalent is the evolutionary perspective afforded by the archaeological record, which substantiates the foundational permaculture perspective, that modern agriculture as a livelihood strategy is a relatively recent event, and so should not be taken as the default mode of food production. In my experience this was a consistent narrative heard at several permaculture sites. Further, historical ecology provides evidence that traditional agricultural methods, such as those revived, reinvented, or otherwise mimicked in permaculture gardens, are less environmentally detrimental and more sustainable than modernist agronomic approaches (Armstrong and Veteto 2015). Additionally, the influence of ethnobotany is present in the permaculture literature and in practice (Holmgren 2002). Ethnoecologists have long been interested in the myriad ways of human subsistence across varied environments; in particular, ethnobotanists have documented how native plants may be foraged for medicinal and culinary purposes, given the base of local ecological knowledge acquired through informal pathways of learning.

With this historical-if subtle-dialogue between permaculture and anthropology in mind, I aim to bring permaculture gardening, as an applied design science, into dialogue with engaged scholarship, supporting the call for further collaboration between permaculture and applied environmental anthropology (Lockyer and Veteto 2013:14). This aim is inspired by my time as a student-practitioner of permaculture in Central and Eastern Europe (CEE), where I observed the tenants of permaculture utilized as the foundation for an alternative strategy of livelihood in unexpected and meaningful ways. Understanding these ventures in alternative agriculture as more than oddities at the edges (of Europe, of academia), I argue that the potential for permaculture as a point of engagement in applied political ecology hinges on the opposition of permaculture to nature/culture dualisms, evidenced in approaches to social and ecological challenges as confronted and navigated by its practitioners. To illustrate this claim, I introduce my fieldwork in CEE as a case study in social permaculture, highlighting permaculture's status as a design science that merges social and ecological systems in its highly adaptable approach to livelihood. Finally, I conclude with a discussion of pathways for engagement, or the 'operationalizable' possibilities for permaculture that warrant the attention of an applied and socially just political ecology (Veteto and Lockyer 2015).

\section{Lay of the land}

\section{Permanent agriculture}

While the concept of permanent-or renewable-agriculture in Western literature dates to early colonial observations of traditional farming methods, permaculture as a portmanteau of permanent agriculture was first described by Australians Bill Mollison and David Holmgren in their 1978 publication Permaculture One. Essentially, permaculture principles seek to maximize output while minimizing effort by

\footnotetext{
2 The names used throughout this account are pseudonyms.
} 
mimicking nature's efficiency. These concepts, since developed by numerous other practitioners and now taught internationally, are intended to be applicable to any location at various scales, utilizing ecological theory and incorporating social components. Elements in permaculture design are prized for their multifaceted purposes, efficient use of space, and utilization of natural checks and balances. This informs permaculture design; for example, many practitioners divide their garden into zones with consideration of where the gardener will most reliably interact with plants: Zone One is closest to the residence and is home to more high-maintenance or most-used plants, while Zone Five is the least-managed, least-accessible area. Permaculture zones and design strategies can be shaped to fit any space and reworked to meet different wants or needs (in Australia, for example, Zone Five may be shaped in a way to allow for better wildlife viewing).

The twelve principles of permaculture design, as outlined by Holmgren (2002), are:
1) observe and interact;
2) catch and store energy;
3) obtain a yield;
4) apply self-regulation and accept feedback;
5) use and value renewable resources and services;
6) produce no waste;
7) design from patterns to details;
8) integrate rather than segregate;
9) use small and slow solutions;
10) use and value diversity;
11) use edges and value the marginal;
12) creatively use and respond to change.

These twelve principles are in service to perhaps the most important tenants of permaculture, a core set of ethics: Earth Care, People Care, and Fair Share. Earth Care is addressed through an emphasis on the sustainable and respectful use of natural resources. People Care and Fair Share do more to emphasize the social aspect of food production; the former involves focus on healthy, holistic societies; while the latter aims for equitable distribution and limits on consumption with the goal of helping achieve social and environmental justice. As illustrated through example below, these principles are often interpreted through both social and ecological lenses.

While not discussed in detail here, it is worth noting that permaculture is one of many diverse and innovative approaches to sustainable food systems. Agroecology, the study of ecological processes within agricultural systems, is one complementary field that is not connected to any specific method of farming (for a primer, see Gliessman 2015). Regrarianism (a portmanteau of regenerative agrarian) is another, more recent approach with origins in Victoria, Australia. Like permaculture, regrarianism adheres to a framework, The Regrarian Platform, which includes human and natural elements according to context and scales of permanence, conceptualizing sustainable agriculture as an exercise in "regeneration, restoration, rehabilitation, rekindling, and rebooting" production at the landscape level (Doherty and Jeeves 2015). Biodynamic farming, developed by Rudolf Steiner, is an early example of sustainable agriculture that unites ecological processes in organic farming with an emphasis on spiritual and mystic viewpoints (see Leiber et al. 2006). These and other alternatives to agriculture-as-usual are inspired by a holistic approach that considers agricultural systems as social-ecological systems.

\section{Fieldsites}

In this article, I draw primarily from fieldwork in Shipka, a town in the Balkan Mountains of Central Bulgaria, as well as a subsequent visit to Shipka, which was part of a larger volunteer farmstay tour of three Central Balkan towns: Shipka, Bulgaria; Škofljica, Slovenia; and Opovo, Serbia in June to September 2011 (Figure 1). I was originally aiming to better understand the assumptions, motives, and guiding philosophical frameworks that underpin permaculture as a collective movement hinging on individual worldviews, and as 
an agroecological project with social and ethical tenants. My ethnography in Shipka was rooted in my participant-observation as a student and volunteer as well as permaculture garden design course participant. Shipka is a town with several permaculture households, a forest garden project, and an active educational center; I draw the bulk of my data from each of these sites. ${ }^{3}$ Some references are also made of my time in the towns of Škofljica (a very small village with one permaculture homestead) and Opovo (a small suburb of Belgrade where a commuting resident revived a centuries-old farmhouse and garden utilizing permaculture principles). These visits took place within a three-year period (2010-13) during which I resided in Budapest, Hungary.

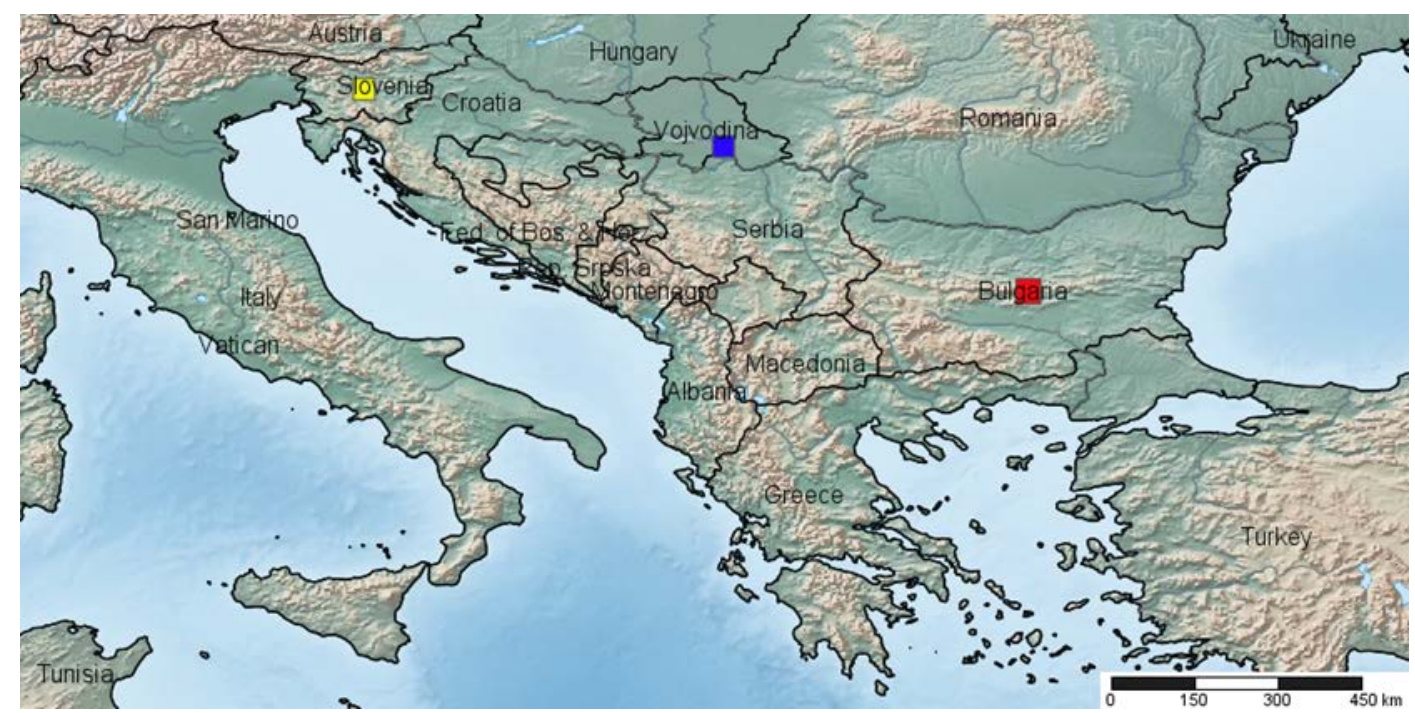

Figure 1: Map of Sites: Shipka, Bulgaria (study site, red); other towns referenced: Škofljica, Slovenia (yellow); Opovo, Serbia (blue). Source: A. June Brawner.

\section{Contextualizing permaculture in CEE}

Shipka is not extraordinary compared to small-town life in other CEE countries, revealed in ethnographic accounts (e.g. Cellarius 2004; Humphrey 2002). Most young people hold wage-earning jobs but, as Cellarius writes in her Bulgarian account, "when inflation turns monthly wages into the equivalent of pocket change, one begins to question the logic of going to work every day versus looking for another activity" (2004:150). For the older generation (and some of the younger) this other activity remains subsistence farming, which is closely tied to social capital between villagers; residents bring gifts of homecanned fruits and vegetables when they visit friends, assist in the birthing of neighbors' animals, and are generous in the sharing of their homemade spirits (rakija). In Shipka and in Opovo ${ }^{4}$ I encountered similar characters: the man with the distillery, the man with the straw, the woman with the cheese. Items are traded, bartered, and gifted in addition to formal exchanges of cash; small herds of goats are led by resident men to be taken to the communal flock each morning. The easy but steady tempo of village life mirrors seasonal rhythms, which serve as a common pattern that unifies both locals and permaculture gardeners.

A contextual understanding of permaculture within CEE and other transformational ${ }^{5}$ regions must therefore refer to the multifaceted marginality of their socio-ecological landscapes: geographically,

\footnotetext{
${ }^{3}$ Shipka hosts the Balkan Ecology project, run by expats and conducting permaculture research, cultivation and permaculture design training. Seeds and veggie boxes are shipped across Europe. http://www.balkep.org

${ }^{4}$ I was not personally introduced to similar people in Škofljica, which was a more removed, intentional, self-contained homesteading site.

${ }^{5}$ The pervasive consideration of CEE as a 'transitional' region appeals to a teleological model of development that is often Western in orientation; rather, I refer to this case study as existing in a region of transformation, situated 'in between'-a time and place that calls into question the mutual exclusivity of communism and capitalism, rural and urban, progress and regression, and other familiar categories and narratives in the social sciences.
} 
politically, and temporally. Such liminal, transformative circumstances can be destabilizing and liberating in their open-endedness and possibilities (Stoller 2008). Intermediate agricultural systems such as permaculture can prove to be more socially, economically, and ecologically sustainable and beneficial, but they are commonly overlooked by officials and policy makers (Wiersum 2004). However, particularly in CEE states, livelihood strategies do not always wait for policy to catch up. Citizens in postsocialist states are not unfamiliar with second, or informal, economies, and the 'peasantry' is often associated with black market practices (Fox 2013; Stahl 2010). As one Hungarian friend related to me as we navigated immigration bureaucracy, they have "always been used to finding the kis kapu": the "smaller-gate-within-the-larger", or what I might refer to as a loophole. In this way, an everyday, cunning intelligence, metis—as Scott (1998) has asserted-is not just disappearing, but it is simultaneously being generated under novel pressures.

\section{Social permaculture in CEE: a case study}

\section{Vignette I: The principle of diversity: migrants and other transplants}

'образцов дом' reads a sign hanging on the gate to John and Gwenn's property in Shipka, Bulgaria. They presume the sign is as old as communism. They are permaculture gardeners. The sign was there when they relocated from England and bought the house. Not being native Bulgarian speakers, they translated the text but were still puzzled by its meaning. I added it to my notebook and spoke to Georgi (owner of a local guesthouse) the next morning about its significance. He was impressed, and related to me that this sign had been an important and prestigious marker during the communist period. These coveted signs were awarded to the best-kept, best-maintained yards in order to set an example for others to follow. Today, as anxious neighbors and nosy passers-by pause to gaze into the unusual gardens, they must first look past the glaring, prized signage that informs them that they are looking at an 'Exemplary Home.'

This mark of distinction, now carrying a tone of irony, would have originally been placed on a manicured, green, homogenous and weed-free lawn. The difference between this intended criteria and the current aesthetic of the lawn-turned-permaculture project is impossible to miss. When I first arrived, David (a long-term American volunteer at John and Gwenn's permaculture farm, who would subsequently relocate to Shipka permanently), asked if I had seen other yards in town and noted how different they appeared from permaculture yards. The occasional peeping eyes of nosy neighbors through the fence confirmed that they, too, noticed the difference. The general tendency of permaculture to mimic patterns in nature leads to results that are visually distinct from more manicured properties (Aistara 2013; Egoz 2000; Garoian 1998; Luke 1992), inspired by permaculture principle 7: design from patterns to details (Holmgren 2002). Much of the manual labor in permaculture involves human activity directly shaping the earth into the most space- and water-efficient patterns and shapes; including spirals, mandalas, and waves—all shapes found in 'non-human nature', and noticeably missing from most of Shipka's orderly, though often equally edible, yards.

Such conspicuous differences have caused misunderstandings within the town. Georgi, at the local guesthouse, admitted, "They do some strange things over there, but I suppose it's interesting — when you're young. Everything is interesting when you're young." He noted that their methods looked unusual, and that their project had overflowed into the neighboring property. Permaculturists-both local and visiting ecotourists - were equally conspicuous. Permaculture events in town — which often include drum circles (also noticeably absent from non-permaculture households) - are scorned by one elderly neighbor who blasts Soviet marches from her window beginning at six the following morning; drum circles, she once communicated to her neighbors, are not music.

Meanwhile, Damyan had been planting a symbolic rebuttal to high modernist conventions and skeptical locals by scattering clover (Trifolium pretense) in his Bulgarian clients' yards: a plant most commonly referred to as a weed, something more often eradicated than propagated. He argued that this lowgrowing, self-fertilizing plant's stigmatized status is an arbitrary one that dates to World War II herbicide manufacturing and marketing. There are echoes here of Robbins's account of industrial support for the creation of herbicide rich American lawns (Robbins 2007). Stinging nettle (Urtica dioica) is another ubiquitous so-called weed in Bulgaria. As Damyan puts it, nettle is like poison ivy in North America: a "gatekeeper to the forest" which, as he explained, is a plant that guards the woods and allows only a select few to handle it without negative repercussions. In essence, this 'weed' is the one that 'weeds out' those who would take advantage or misuse the forest's resources. As it happens, Damyan has the ability to handle either 
poison ivy (Toxicodendron radicans) or stinging nettle without pain or allergic reactions, which he interprets as symbolic of his integration with the plant and animal world. He explained that stinging nettle is edible, provides a range of nutritional benefits for humans, and is even palatable when crushed in a salad or cooked, tasting similar to spinach (Spinacia oleracea). Permaculture gardeners in Shipka argued that nettle; along with hogweed (Heracleum sphondylium), chickweed (Stellaria media), dock (Rumex obtusifolius), and the other 'weedy' staple foods are used in lunch salads and other dishes were once cultivated and used by locals who were "more connected to the land"—after all, nature has no weeds. To legitimize another popular weed, one informant even suggested the use of hemp in guild planting. ${ }^{6}$ This "little brother to the three sisters," as he called it, may be beneficial when grown alongside the traditional three sisters plant guild of corn, squash, and beans. I finally questioned Damyan directly: "What is a weed, then?" to which he coolly replied, "I don't believe in weeds."

\section{Permaculture relationships}

In its continual evolution, permaculture has been understood as an increasingly socially relevant project (see Ferguson and Lovell 2014 for a systematic review). Social permaculture prioritizes the People Care ethic advocated by permaculture gardeners. This is an emancipatory proposition; in the same way that permaculture gardening optimizes relationships between all variables, values the marginal, and has 'no weeds', social permaculture provides a framework for inclusiveness, equity, and social justice that minimizes outliers. Mutually beneficial relationships fostered in the garden are replicated in the social realm (Macnamara 2012), materializing as "contemporaneous interpersonal equity and intertemporal environmental justice", particularly through the redistribution of surplus (Suh 2014:83). Reminiscent of these themes, permaculture was explained to me by several CEE gardeners as permanent culture or permanent relationships. These relationships are not just about having more things on a farm, but increasing existing interrelationships in quantitative and qualitative ways (Aistara 2013). It is this network of relationships, this connectivity-rather than the things they constitute - that defines permaculture's adaptability and systemic resilience.

Damyan's willingness to challenge socially-constructed categories extends to his self-assessment regarding his nationality; born in Canada, he identifies as Bulgarian through a narrative that is more complex than geography. He, like other gardeners in Shipka, have learned to use and value diversity (permaculture principle 10, Holmgren 2002), a sentiment that extends beyond weeds. Scott (1998) discusses the legitimization of categorizations for people as requisite for the legible populations required in statecraft; Aistara (2013) extends this concept to weeds in permaculture gardening, which often distinguishes permaculture yards from others and strikes discordant notes with neighboring households. Indeed many people in Shipka are proud of their weed-free lawns, which would have once been honored with signage acknowledging their "exemplary homes." With a similar pride, one local business owner in Shipka reported that they had "no minorities" in their town. When pressed, he explained that he was referring to the marginalized Roma, Muslim, and Turkish-speaking populations who I encountered in nearby villages (notably, the English gardeners escaped his evaluation). John and Gwen, themselves migrants to Central Bulgaria (though often framed as 'expats'), were in contact with several of these people and engaged with them in personal and business matters; they valued their knowledge of animal husbandry, seed saving, and other areas-in the process enhancing the resilience of their own livelihood through valuing the marginal (permaculture principle 11, Holmgren 2002).

The status of plants and people as native or exotic is a basic example of the somewhat arbitrary, culturally-constructed nature of such typologies. The permaculture gardeners' reluctance to place people and plants into categories such as weeds, natives, or exotics was mirrored by their being the only people in town who hosted the solitary Roma family as guests in their home. While some gave preference to locally-sourced seeds (for reasons related to time-tested fitness of a varietal), they were not opposed to acknowledging and

\footnotetext{
${ }^{6}$ The use of guilds in permaculture is notably distinct from its use in ecological circles; the former uses guilds to describe an assemblage of mutually beneficial plants while the latter describes a series of species that exploit similar resources or occupy the same niche. For further discussion on this and other idiosyncratic uses of ecological terminology in permaculture, see Ferguson and Lovell (2014).
} 
utilizing 'less-native' species of plants (squash, for example) or animals and questioning the native/non-native distinction (tomatoes, it was pointed out, are a relative newcomer yet an intrinsic part of Bulgarian cuisine).

\section{Vignette II: The creation of abundance and the 'monoculture' of capital}

"What is wealth?" Damyan asked a group of thirty permaculture course attendees. They had come from Bulgaria, Romania, Latvia, Hungary, America, and Israel; leaving their respective ecovillages, suburban homes, and studio apartments for a weekend spent in a small Bulgarian town, hoping to collaborate and share mutual inspiration. When nobody answered immediately, he repeated the question in Bulgarian: how do you define wealth? As hands began to go up, the answers were eventually compiled into one category: the creation of abundance. He began to write everyone's answers on the chalkboard under this heading: abundance of time, abundance of freedom, of freewill. Capital did not make it onto the board, nor did salary or benefits, material possessions, or even shelter. That these gardening enthusiasts, reclining at the foot of the Balkan Mountains on a kaleidoscope of quilts, would put such value in the non-material is not surprising. That this group of young people would challenge one another to reproduce these values in their daily lives, however, was unexpected for me as a newcomer to permaculture methods and philosophy. For these 'students of nature', permaculture offers abundance on their own terms-in units of time, freedom, and freewillconceptualized as a diversification of investment that runs counter to capitalism's "monoculture of commerce."

In his permaculture course, Damyan concluded that limiting concepts of wealth to capital is a mistake; it creates a "monoculture of commerce" equally as dangerous and unstable as the monocultural farming that permaculture strives to correct. In this view, capitalists are monoculturalists; they "have all their eggs in one basket." The lecture that followed this observation included an argument for subsistence living, citing what was called 'primitive' work compared to 'modern' work. So-called primitive work (that done by people who, in the past, practiced horticultural or foraging subsistence methods) required only about ten hours of work weekly in order to survive. In a tone reminiscent of Sahlins' Original Affluence (1972), Damyan concluded that the advent of large-scale, monocultural agriculture practices brought about longer work weeks and introduced a number of previously unknown diseases and degenerative illnesses. Reformulating his original question ("How do you define wealth?"), he asked, "Which of these two types of people have more wealth (primitive or modern)?" For him, permaculture is not about privileging any one system-economic or otherwise-but rather about striking a balance and making due.

\section{Wealth and weeds}

Notably, the conceptualization of wealth discussed in the permaculture course seemed to play into nostalgia for socialist Bulgaria, even across the young group of course attendees. This was present when I spoke with both Bulgarian and international participants: "These people [Bulgarians] don't realize how rich they are," Richard, another English permaculture gardener living in Shipka, told me as I was struggling to uproot a small fruit tree in his yard. Richard insists that communism would have worked if people "hadn't become greedy", a trait which, he believes, is not inherently a part of human nature. He contrasts this with permaculture, which he feels is "the only way."

As with similar rural subsistence projects, permaculture in postsocialist Europe serves "as a constant reminder of the unfulfilled promises of modernity" (Hervieu-Leger 2000:77) to both visitors and locals, which is perhaps made more striking by the presence of Western 'refugees.' It has been suggested that a reconsideration of Engels's (1976) assertion that what is good for the working class is good for all of society might guarantee food security and sovereignty for all, but not a luxury home and sports car for everyone (Mies and Bennholdt-Thomsen 2000). This is not to say that permaculture endorses a brand of socialism (in my experience, political allegiance can vary widely within such sites), but that it engages with a utopian vision that opposes both communism and business-as-usual capitalism. For Richard, at least, permaculture offers retreat from the neo-liberal capitalist agenda that he could "never really embrace" in England or the United States.

Under the economic strains of crisis, those whose hopes rest upon capital, whose wealth and livelihood relies on the global market, perceive economic collapse as the end of the world; those who practice subsistence - though often associated with rurality, poverty, and backwardness—are more immune to these 
threats. Indeed, in Shipka and at other permaculture sites in CEE, subsistence gardeners have been largely able to "ignore the economic crisis" (Aistara 2013:114). Ignoring economic crisis is facilitated in Shipka by permaculture gardeners' reconceptualization of wealth and the agency to realize wealth in novel ways, namely through valuing renewable resources in the landscape (permaculture principle 5, Holmgren 2002).

Permaculture and Intermediate land use systems may be used to localize what would otherwise be a reliance on an increasingly expanding network, which becomes particularly relevant with the accession of many CEE states to the European Union. In this case, the localization of livelihoods creates a space for subversive strategies of subsistence. Feminist-Marxist scholars recognize this subversive potential in their call for a subsistence perspective that emphases autonomy for societies who depend not on "money, education, status, and prestige but on control over means of subsistence...(and) some independent money income"; essentially, this includes "the capacity of communities to produce their life without being dependent on outside forces and agents" (Bennholdt-Thompsen and Mies 2000:3-4). At the permaculture sites I visited in CEE countries, this does not mean a return to collective farming but something that more closely resembles 'private times' before communism, when informal, cooperative land management was still prevalent, crop diversity higher, and farming less-dependent on mechanization (Cellarius 2004).

\section{Vignette III: Permaculture epistemes: ethnoecology, experiment, and each other}

I was flipping through the pages of Holmgren's (2002) well-known text when Richard told me he respected the way I held a shovel but disproved of my relying on books; in fact, since his foray into permaculture gardening he had become quite critical of the use of written, academic materials in permaculture education, a sentiment that extended to his skepticism regarding my own endeavors as a visiting anthropologist. He insisted that people truly learn permaculture only by doing, by observing. "You plant something and watch it", he told me, "If it doesn't like it, the plant will tell you-by dying!- -and then you try again in a different location or with different soil or hydration."

When I asked Damyan how he perceived local gardeners' approaches to learning permaculture, he told me that he thought many Bulgarian gardeners to be highly superstitious, only planting when their "mood is right", and reading the weather for signs and symbols. According to Damyan, they expect that he is equally attuned to these things and extremely spiritual in his approach because he is a permaculture teacher. He explained that, while he loves to entertain these ideas, his "logic gets in the way." Damyan and John both refer to permaculture publications and default to observational evidence as a guiding tool. To illustrate their point, they gave an account of biodynamic gardeners, many of whom attend permaculture courses. They were described as gardeners who follow astrological calendars and often practice sympathetic magic, such as the ritual burial of specific minerals or animal remains, but none of which-according to John and Damyan-are supported by empirical evidence. They, on the other hand, employ a certain skepticism in their agriculture and conservation efforts. John, for example, learns permaculture primarily through literature and practice in his gardens, where he designs and carries out controlled experiments to compare permaculture techniques with other, conventional non-permaculture techniques. Documenting these comparative studies, he posts the results on a website in English and Bulgarian so that this information is accessible to other gardeners. He explained that testing permaculture methods for their efficiency and sustainability without bias against other techniques is imperative, because taking any one system for granted as the only way-even permaculture itself_-is what "got us in this [environmental] mess in the first place."

\section{Ways of knowing}

The presence of multiple, simultaneous ways of knowing in Shipka is another display of permaculture's social inclusivity. While Holmgren acknowledges that "permaculture was conceived within academia" (2002:xxii), it has received negative reception; perhaps there is little appreciation for such a holistic approach in an academy of specialists (Veteto and Lockyer 2008). Permaculture design principles are rooted in ecology, horticulture, architecture, and other disciplines; however, the inclusion of the agentgardener, their considered observations (also a permaculture design essential), and measured responses and interactions within their system are inherent to success. The blurring of 'expert' and 'lay' knowledges creates a space for collaboration and inclusion. 
Richard's observing and interacting sentiment (permaculture principle 1, Holmgren 2002), and simply 'getting your hands dirty' echoed an emphasis on embodied learning and practice, the [re]honing of a particular metis, in this case a localized set of skills, learned only through experience, sometimes lost to modernity (Scott 1998). Such experiential knowledge is highly sought after, as exemplified by the turnout during Bulgaria's first permaculture course held during my stay in the spring of 2011, as well as the willingness of long-term volunteers who aim to learn by apprenticeship. David also interpreted this embodied practice through creating art and observing and illustrating local flora and fauna, which he considered to be "the best way to learn."

Meanwhile, Damyan's garden design course included ecological language and explanations of systems thinking, including diagrams and flow charts to illustrate the in(put)s and out(put)s of chicken tractors (see Figure 2). Further lectures on permaculture design included the replacement of chemical inputs (such as pesticides and herbicides) with biological checks such as crop diversification (polyculture); and erosion and evapotranspiration were countered through insulating layers of mulch (much like a forest floor); this way, farm-to-table becomes table-to-farm. To apply these ideas, garden course groups constructed compost piles using different ratios of materials, dug out vegetable beds, and planted a living fence of hedges, berries, and other perennials in an activity that appealed to Richard's embodied approach. Participants also collected soils in order to feel their texture, sang Bulgarian folk songs about forests together, created salads out of 'weeds' and then tasted the results for lunch.

Another take-home lesson from Damyan's course was the inclination to "waste no more" (permaculture principle 6, Holmgren 2002). This extended beyond the site's compost piles and worm bins to the surrounding village, where we salvaged materials nearly every day from neighbors who were hoping to get rid of wood scraps, grass/weed clippings, sawdust, or manure. On-site compost toilets provide fertilizer (humanure) with the added bonus of "not defecating in your drinking water." Chicken tractors are used to transform household organic waste into nitrogen-rich manure; creating a nutrient-dense, 'tilled' areas ready for planting without chemical fertilizers, tilling, or weeding (and with fresh eggs for daily consumption). These ideas were presented as a rational, conscious realignment with ecological processes but presented in ways that appealed to a heterogenous group of gardeners, university students from Sofia, elder villagers, young families and the like.

Like other permaculture principles, the aim to produce no waste is inspired by the recognition that nature has no waste: a revelation that is equally ecological (all 'waste' is potential input, viewed from another perspective) and social (waste, like weeds, is a constructed category that can be reconsidered and redefinedor deleted altogether). That such a holistic, social-ecological approach would result in the inclusion of many ways of knowing is not surprising; that they co-flourish is perhaps the key 'take-home' permaculture garden course lesson. Recognizing this unusual space for collaboration in sustainable development is the foundation for further discussion of permaculture as applied political ecology.

\section{Discussion: operationalizing permaculture as applied political ecology}

Permaculture is more than a social movement or venture in alternative agriculture; rather, the inclusion of the social element in the ecological processes of food production lends permaculture its holistic perspective and potential for longevity. Moreover, permaculture design is highly contingent upon the literal and figurative lay of the land; by adapting to shifting social and political terrain it flourishes in its sociallyinclusive orientation. Further attention from applied environmental anthropologists might bolster such projects beyond the scope of a social movement or as merely an 'alternative', and may evaluate seriously the potential for permaculture as an oppositional framework (Allen et al. 2003). This opposition is characterized by an approach to development that prioritizes social and ecological relationships simultaneously. My time in CEE provided only a brief glimpse into the numerous possibilities for permaculture at the local level. The the broader implications of the permaculture framework as both a gardening strategy and a reconceptualization of eco-social relations should not be underestimated (Veteto and Lockyer 2008).

In the following sections I will discuss permaculture's intersections with theoretical and applied social-ecological sciences and introduce possibilities for further incorporation of permaculture into research where the objective is social and ecological justice. To illustrate these points I return to my framing of permaculture as oppositional to nature/culture binaries through the embracing of social-ecological strategies. Key to my approach is that permaculture design situates humans and social relationships as existing within 
social-ecological processes rather than outside of or residing over them, a reorientation that is inherently oppositional to top-down development.
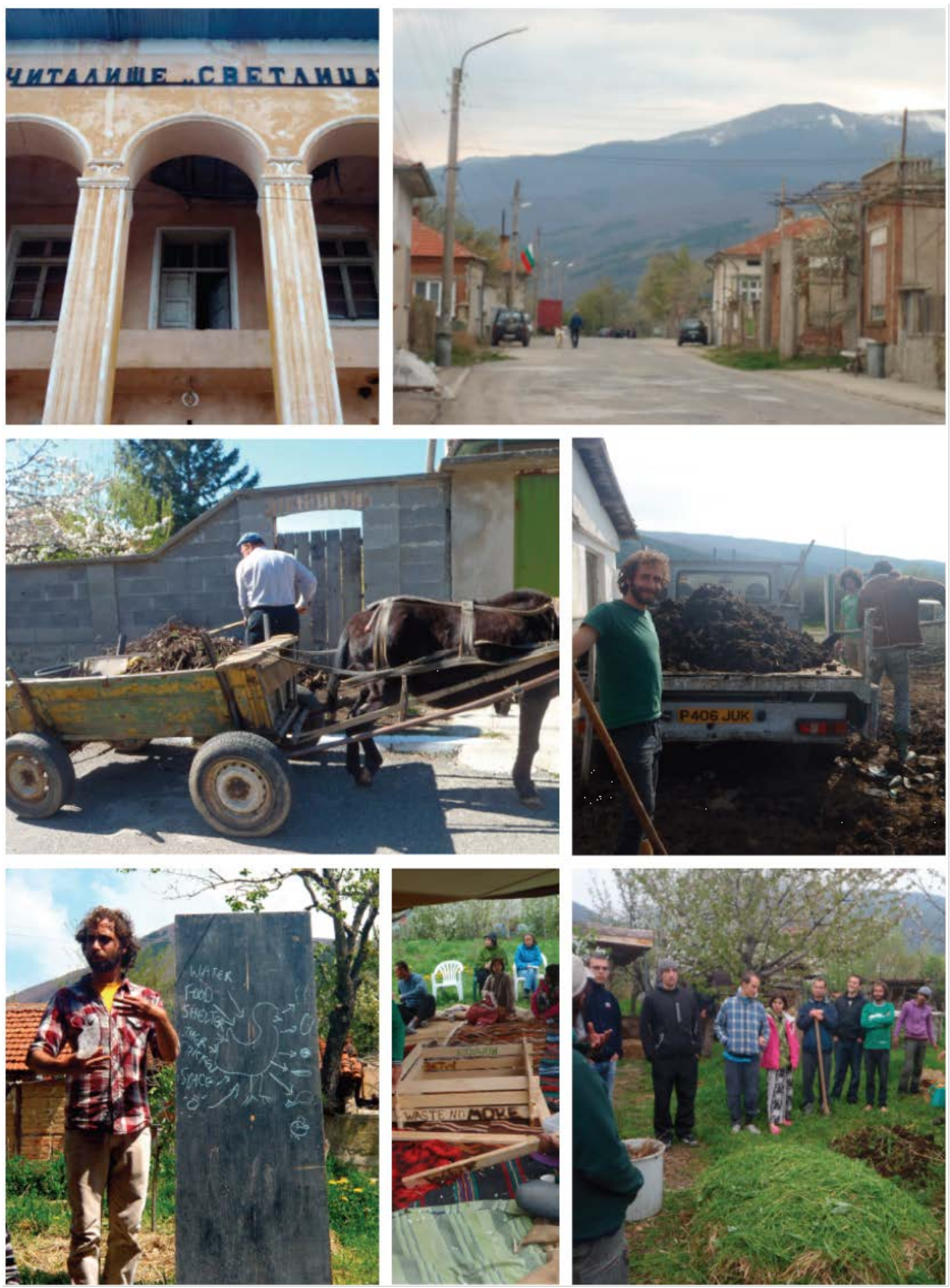

Figure 2: Garden Course Collage. Top left: The derelict cinema (kino) and City Hall serve as reminders of what Georgi calls the "glory days" of Shipka; Top right: a neighbor walks his goat home from the communal herd, or "goat school"; Center right: a local man shovels organic 'waste' just before being interrupted by permaculture gardeners hoping to repurpose it; Center right: Damyan, John, and David harvest 'cow trash' for the gardens; Bottom left: Damyan teaches about chicken inputs and outputs for the garden course; Bottom center: Creation of the "Waste no More" worm bin; Bottom right: The permaculture garden course participants learn the science and art of compost piles. Source: A. June Brawner (April-May 2011). 


\section{Socio-ecological solutions for socio-ecological problems}

The conscious inclusion of the human element in permaculture agronomy is a lived-out, subversive critique of nature/culture dualisms (Lockyer and Veteto 2013). It has been said that the radical, if gradual, shift from foraging to agriculture "must be understood... as a cognitive or symbolic transformation that redefined human self-awareness" (Starr 2005:8). This awareness would have presumed the ability to manipulate the land, select for the most efficient crops, and produce an unprecedented amount of food annually. Perhaps we are at such a juncture today, as human consciousness-largely due to the conspicuous nature of our own destruction and ensuing environmental crisis-must again be redefined in view of our relationship to foodways. Permaculture is one answer to the agricultural post-productivist question; it promotes environmental stewardship, decentralization and increased cooperation, utilization of polyculture, and emphasizes the need for renewable resources (Suh 2014). If permaculture was "way ahead of its time" for its incorporation of interdisciplinary knowledge sets and lay expertise (Veteto and Lockyer 2008), it is equally innovative in its coupling of social and ecological systems; permanent culture and agriculture is not only a nod to the social context of agricultural endeavors, but may be understood as a framework for implementing sustainable social-ecological systems (SES).

An SES may be understood as a unit of functionally-linked biological, geological, and social components; the system may also include institutions and actors on many scales simultaneously (Redman et al. 2004). Before systems approaches to SES were codified and made popular in formal assessments of ecosystem services and resilience (e.g. Meadows 2008, Walker and Salt 2006), permaculture gardeners were observing interspecies dynamics (permaculture principle 1, Holmgren 2002), recording thresholds and leverage points, and intervening in feedback loops between various social and ecological variables in the everyday space of their own gardens (this last point speaks to several permaculture principles, notably produce no waste and capture and store energy; permaculture principles 2 and 6, Holmgren 2002). What is more, permaculture gardeners have factored in an ethical framework and agenda for social justice. I suggest that a systematic approach, which includes both social and ecological drivers and impacts, is one reason permaculture may be described as a 'revolution disguised as gardening' (Burnett 2008); in a time of coupled social and ecological crisis, the implications for the realignment of the ecological and the social provided by permaculture are profound.

\section{Permaculture permutations}

That permaculture principles are realized in countless ways within an international movement speaks to its adaptability and resilience across heterogenous geophysical, political, and social landscapes. Moreover, permaculture remains largely outside the influence of large institutions and relies on participatory research and popular support (Méndez et al. 2013), creating a space for collaboration across disciplines and backgrounds. My experience in the Balkans highlighted this flexibility as agroecological transitions mirrored political transitions. As outlined above, permaculture is an accessible SES framework; it is inherently adaptive and prioritizes efficiency without sacrificing system resilience. For example, the utilization of polyculture may require additional manual labor during harvests, but this is levied against the resilience of mutually-beneficial relationships between a heterogeneous group of crops (disease resistance, companion plants having differing nutritional requirements, etc.) In addition, the preference for perennial food crops, which may yield less edible mass per season, is justified by the long-term benefits of reduced annual planting labor and soil tillage (Kelsey 2014; Toensmeier 2007).

Permaculture principles have shown their inherent adaptability; moving forward, it is worth questioning whether permaculture can and should be 'scaled-up.' Veteto and Lockyer (2008) note that international agricultural and development centers have not utilized permaculture as an approach in any significant way and suggest that this may be for the best, as current top-down approaches to development are structurally, contextually, and epistemologically incongruent with the horizontal, inclusive network of permaculture as an alternative. Others identify permaculture as inspiration for a "...paradigm shift in policymaking from environmental managerialism to environmental stewardship" (Suh 2014:93), calling for aggressive policy measures in support of permaculture and the recognition of positive gains (such as reduced energy consumption and the repurposing of waste) within the context of larger economic structures, noting that small-scale systems of food production are not necessarily efficient or environmentally benign. 


\section{A space for opposition}

Localizing subsistence economies may act as a subversive consolidation of agency in marginal landscapes, but what are the broader implications beyond these individual sites? Following Allen et al.'s (2003) use of alternative and oppositional, an applied political ecology may ask whether permaculture act as an alternative by operating within existing structures and allowing a space for withdrawal, or can it be oppositional in aiming to implement a new structural figuration? To some degree, each permaculture action or site (from small farm to windowsill box) may function largely as an alternative. These sites operate via withdrawal from larger markets and create a distinct, local space for food production and community while manipulating existing structures (in the case of CEE, this includes the privatization of common land, EU membership and associated residency allowances, disparity between the Euro and other currencies equating to disproportionate buying power, etc.) and do not operate to amass capital in the traditional sense. However, the core tenants of permaculture practice, in all their iterations, grant permaculture the potential to be oppositional because it is fundamentally counter to the foundations on which the larger food-producing and political systems are based, namely the exceptional status of humans.

Because permaculture is more than small-scale food production-it draws on socio-ecological networks, simultaneous alternative epistemologies, and stewardship of place and community-new relationships replace old hierarchies, entailing a rejection of hegemonic forces and narratives of power. This emphasizes quietly subversive methods that operate as anti-foundational critiques of positivist epistemology, notably 'high-modernist' agricultural science (Scott 1998) and Western cultural dominance. Permaculture can be a performance of opposition, an acknowledgment of structural shortcomings, a suggestion of hope, and a productive manifestation of subaltern ways of knowing. Real structural opposition through permaculture is viewed as feasible by practitioners in Bulgaria, where environmental unrest and dissatisfaction in the 1980s led to large-scale uprising and eventually to the fall of communist regimes (Paskaleva et al. 1998; Dawson 1996).

Essential to permaculture's position as either alternative or oppositional is the collective-overindividual approach championed by permaculture gardeners - this runs counter to dominant individualist narratives (Suh 2014). This collective orientation may also find a well-suited application in the pursuit of permaculture knowledge itself and it is a lesson to academic 'experts' and specialists. Reconceptualizing permaculture knowledge as a collective endeavor, or as a commons, speaks to Veteto and Lockyer's (2008) assertion that the holistic approach to permaculture is inherently incongruent with the highly-specialized and exclusive nature of institutionalized knowledge production. I suggest that, while there is no room for the lone specialist in permaculture practice or research, we might also "make the best of things" and follow Hemenway's (2009) lead to reconfigure our expertise into guilds of complimentary epistemologies in an effort to create a more inclusive—and equitable—-foundation for permaculture study and engagement.

\section{Regeneration and remembrance in-situ: redefining progress}

Permaculture was defined by several informants as regenerative gardening; it is this potential for resurgence that inspires many of its practitioners, who see that this process of "...regeneration is focused on creating an ecologically driven local agrarian economy that primarily functions as a provisioning mechanism of livelihood and food security, and instrumentally also empowers people through the creation of local selfdependent communities" (Natarajan 2005:409). If permaculture-as several gardeners related to me-is the singular "way", how had something universal become a project of the local? In my experience in Shipka (and at similar sites in Slovenia and Serbia), emphasis on locality and traditional methods hinge on relationshipswithin the community, within the garden, and with the past-as well as the inclusion of diverse simultaneous epistemologies.

Opposing the general motion of what many in CEE consider to be 'progress', the CEE iterations of permaculture that I witnessed in Shipka, Opovo, and Škofljica hinge on the fact that, as many of my informants insisted, it is nothing new. It draws from localized, indigenous, intergenerational knowledge and makes use of natural, social, and regional assets; as Fox (2013:167) illustrates in her Romanian account, "permaculture is not a static framework; it is alive and growing with the people who use it." Relating her family's history in the small town of Shipka, Niki (a Bulgarian permaculture gardener) argued that towns like Shipka "have always been ecovillages", by which she meant a sustainable, integrated garden-and-village in 


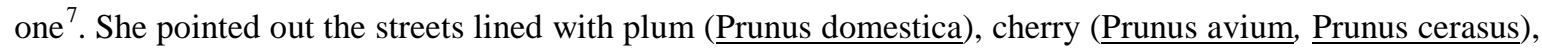
and apple trees (Malus x domestica), adjacent forest (which is frequently foraged for wild garlic, nettle, or mushrooms), and the common spring-fed irrigation system. Her grandmother planted her vegetables with a fork long before "no-till" agriculture was popular. That permaculture practices resemble traditional agriculture, particularly in CEE countries, has also been noted in Latvia (Aistara 2013) and Romania (Fox 2013). But if permaculture is reminiscent of traditional Bulgarian gardening, then why do permaculture gardens sometimes strike such a discordant note with some of the locals?

Today, older generations in Shipka are confronted with a post-socialist project that appears "backwards" and "strange", if only because it seems retrograde. As Fox (2013:175) writes of the Romanian case, the permaculture vision for a feasible and desirable transition

...runs explicitly counter to dominant ideas of 'wealth' and 'prestige' that were common in Romanian visions of the future...In other words, their disappointment is possible only because they believe in the golden age of modernity and improvement originating from the state that they had partially witnessed in 1950s and 1960s socialism.

I suggest that this theme is particularly salient in Shipka, where several permaculture practitioners are immigrants from the United Kingdom, even as media discourse portrays EU immigration patterns as westward-bound.

For many, maximizing this space 'in between' offers the possibility to redefine progress, implement new livelihood strategies that marry traditional practices with contemporary understandings of socioecological systems, and offer a lasting opposition. Permaculture at these CEE sites offers a counter to a narrow, Western-centric notion of progress, creating oppositional frameworks for development. Because of permaculture's social-ecological orientation, growth is judged not by quantity but by quality and in terms of relationships between rather than on fetishized things. Permaculture exists as a highly flexible framework for reform in which the structural failings of the current agro-food system are made manifest in a multitude of subjective, highly individualized ways. During my time on permaculture farms in three CEE towns, no singular permaculture narrative or motivation emerged other than a general trope: dissatisfaction-with environmental management, society, and economy. Only a critical, applied political ecology of CEE transitions elucidates these dissatisfactions and possible alternatives, as permaculture's potential for revolutionary change lies not in its continuity across sites but in its social and ecological adaptability within them.

Through capitalism, nature is "...robbed of its natural character and becomes a factor in production calculations, while the market is ascribed a natural character as if its mechanism were beyond human influence" (Bennholdt-Thomsen and Mies 2000:113). An applied political ecology foregrounds this paradigm: the current economic system is socially constructed and maintained; economies are reified through practice, and appear oftentimes to be beyond the scope of human intervention and reconfiguration. For the permaculture gardeners I met at CEE sites in Shipka, Škofljica, and Opovo, permaculture is more than an alternative to resource-intensive industrial agriculture; it provides an intermediate or 'in between' space for alternative livelihoods, ideas and beliefs. It privileges traditional and alternative ways of knowing while maintaining a scientific skepticism. As such, permaculture also provides fertile ground for applied political ecologists to engage in meaningful participatory research that contributes to positive social and ecological change (e.g. Veteto and Lockyer 2008). While permaculture may not be a fix-all approach for the current environmental crisis, its reconsideration of socio-natural binaries and social inclusivity is a worthwhile endeavor. These possibilities represent a space for opposition and alternative trajectories of sustainable development through reform and resistance in the context of everyday life as - in a land where utopian ventures are not unfamiliar-permaculture has found fertile soil in unexpected ways. Yes, these may be small and slow solutions, but for those who creatively use and respond to change, they are making all the difference (permaculture principles 9 and 12; Holmgren 2002). As a growing number of case studies illustrate (see Lockyer and Veteto 2013), the potential of permaculture in applied political ecology is not in any unified

\footnotetext{
${ }^{7}$ Niki's use of this term represents one of many interpretations of what an ecovillage is (e.g. Lockyer and Veteto 2012). For a discussion of definitions, developments, and recent trends, see Dawson (2013).
} 
theory of gardening, but in its positioning of subsistence as an inherently social-ecological project, grounded in the assumption that truly sustainable foodways necessitate a cultural revolution (Holmgren 2002:xxv).

\section{References}

Armstrong, C.G. and J.R. Veteto. 2015. Historical ecology and ethnobiology: applied research for environmental conservation and social justice. Ethnobiology Letters 6: 5-7.

Aistara, G.A. 2013. Weeds or wisdom? permaculture in the eye of the beholder on Latvian eco-health farms. In J. Lockyer and J.R. Veteto (eds.) Environmental anthropology engaging ecotopia: bioregionalism, permaculture, and ecovillages. New York: Berghahn Books. Pp 113-129.

Allen, P., FitzSimmons, M., Goodman, M., and K. Warner. 2003. Shifting plates in the agrifood landscape: the tectonics of alternative agrifood initiatives in California. Journal of Rural Studies 19(1):61-75.

Basso, K. H. 1996. Wisdom sits in places: landscape and language among the western Apache. Albuquerque: UNM Press.

Belcher, B., G. Michon, A. Angelsen, M.R. Pérez, and H. Asbjornsen. 2005. The socioeconomic condition determining the development, persistence, and decline of forest garden systems. Economic Botany 59(3): 245-253.

Bennholdt-Thomsen, V. and M. Mies. 2000. The subsistence perspective: beyond the globalised economy. London: Zed Books.

Berdahl, D. 1997. Where the world ended. re-unification and identity in the German borderland. Berkeley: University of California Press.

Burnett, G. 2008. Permaculture: a beginners guide. UK: Spiralseed.

Buyandelgeriyn, M. 2008. Post-post-transition theories: walking on multiple paths. Annual Review of Anthropology 37(1): 235-250.

Caldwell, M.L 2009. Introduction. In Caldwell, M.L. (ed.) Food and everyday life in the post-socialist world. Bloomington: Indiana University Press. Pp 1-28.

Cellarius, B.A. 2004. In the land of Orpheus: rural livelihoods and nature conservation in postsocialist Bulgaria. Madison: University of Wisconsin Press.

Cornia, G.A. 1994. Poverty, food consumption, and nutrition during the transition to the market economy in Eastern Europe. American Economic Review 84(2): 297-302.

Creed, G. 1998. Domesticating revolution: from Soviet reform to ambivalent transition in a Bulgarian village. University Park: Penn State University Press.

Dawson, J. 2013. From islands to networks: the history and future of the ecovillage movement. In J. Lockyer and J. R. Veteto (eds.) Environmental anthropology engaging ecotopia: bioregionalism, permaculture, and ecovillages. New York: Berghahn Books. Pp 217-234.

Dawson, J.I. 1996. Eco-nationalism: anti-nuclear activism and national identity in Russia, Lithuania, and Ukraine. Durham: Duke University Press.

Doherty, D. and A. Jeeves. 2015. Regrarians eHandbook 1: climate. Victoria Australia: Regrarians Ltd.

Dunn, E.C., and K. Verdery. 2011. Dead ends in the critique of (post)socialist anthropology: reply to Thelen. Critique of Anthropology 31(3): 251-255.

Egoz, S. 2000. Clean and green but messy: the contested landscape of New Zealand's organic farms. Oral History 28(1): 63-74.

Engels, F. 1976. Origin of the family, private property and the state. In Karl Marx and Frederick Engels, selected works, Vol. III. Moscow: Progress Publishers. Pp 191-334.

Fox, K. 2013. Permaculture ethics to work: progress, hope and commons thinking. In J. Lockyer and J.R. Veteto (eds.) Environmental anthropology engaging ecotopia: bioregionalism, permaculture, and ecovillages. New York: Berghahn Books. Pp 164-179.

Ferguson, R.S. and S.T. Lovell. (2014). Permaculture for agroecology: design, movement, practice, and worldview. A review. Agronomy and Sustainable Development 24: 251-274.

Gliessman, S. R. 2015. Agroecology: the ecology of sustainable food system ( $3^{\text {rd }}$ Ed.). Boca Raton: CRC 
Press.

Garoian, C.R. 1998. Art education and the aesthetics of land use in the age of ecology. Studies in Art Education 39(3): 244-261.

Hemenway, T. 2009. Gaia's garden: a guide to home-scale permaculture (2 ${ }^{\text {nd }}$ Ed.). Burlington: Chelsea Green Publishing.

Hervieu-Leger, D. 2000. Religion as a chain of memory. New Brunswick: Rutgers University Press.

Holmgren, D. 2002. Permaculture: principles and pathways beyond sustainability. Hepburn, VIC Australia: Holmgren Design Services.

Humphrey, C. 2002. The unmaking of Soviet life: everyday economies after socialism. Ithica: Cornell University Press.

Kideckel, D.A. 2002. The unmaking of an east-central European working class. In C. Hann (ed.) Postsocialism: ideals, ideologies and practices in Eurasia. London: Routledge. Pp 114-132.

Leiber, F., N. Fuchs, and H. Spieß. 2006. Biodynamic agriculture today. In P. Kristiansen, A. Taji, and J. Reganold (eds.) Organic agriculture: a global perspective. Collingwood, VIC: CSIRO Publishing. Pp 141-150.

Lockyer, J. and J.R. Veteto. 2012. Ecovillages. In S.G. Beavis, M. Dougherty, and T. Gonzales (eds.) The encyclopedia of sustainability: vol. 8. The Americas and Oceania: assessing sustainability. Great Barrington, MA: Berkshire Publishing. Pp 92-95.

Lockyer, J. and J.R. Veteto (eds.) 2013. Environmental anthropology engaging ecotopia: bioregionalism, permaculture, and ecovillages. New York/London: Berghahn Books.

Luke, T.W. 1992 Art and the environmental crisis: from commodity aesthetics to ecology aesthetics. Art Journal 51(2): 72-76.

Macnamara, L. 2012. People and permaculture. East Meon: Permanent Publications.

Meadows, D.H. 2008. Thinking in systems: a primer. White River Junction: Chelsea Green Publishing.

Mebratu, D. 1998. Sustainability and sustainable development: historical and conceptual review. Environmental Impact Assessment Review 18(6): 493-520.

Méndez, V.E., C.M. Bacon, R. Cohen. 2013. Agroecology as a transdisciplinary, participatory, and actionoriented approach. Agroecology and Sustainable Food Systems 37: 3-18.

Mollison, B., and D. Holmgren. 1978. Permaculture one: a perennial agricultural system for human settlements. Tasmania Australia: Tagari Publications.

Natarajan, T. 2005. Agency of development and agents of change: localization, resistance, and empowerment. Journal of Economic Issues 39(2): 409-418.

Paskaleva, K., P. Shapira, J. Pickles, and B. Koulov. 1998. Bulgaria in transition: environmental consequences of political and economic transformation. Farnham: Ashgate.

Pine, F. 2002. Retreat to the household? Gendered domains in postsocialist Poland. In C.M. Hann (ed.) Postsocialism: ideals, ideologies and practices in Eurasia. London: Routledge. Pp 94-113.

Redman, C.L., J.M. Grove, and L.H. Kuby. 2004. Integrating social science into the long-term ecological research (LTER) network: social dimensions of ecological change and ecological dimensions of social change. Ecosystems 7(2): 161-171.

Robbins, P. 2007. Lawn people: how grasses, weeds, and chemicals make us who we are. Philadelphia: Temple University Press.

Rogers, D. 2010. Postsocialisms unbound: connections, critiques, comparisons. Slavic Review 69(1): 1-15.

Sahlins, M.R., 1972. Stone age economics. Piscataway: Transaction Publishers.

Scott, J.C. 1998. Seeing like a state: how certain schemes to improve the human condition have failed. New Haven: Yale University Press.

Stahl, J. 2010. Rent from the land: a political ecology of postsocialist rural transformation. London: Anthem Press.

Starr, H. 2005. Subsistence: models and metaphors for the transition to agriculture in Northwestern Europe. Michigan Discussions in Anthropology 15(1): 1-48. 
Stoller, P. 2008. The power of the between: an anthropological odyssey. Chicago: University of Chicago Press.

Suh, J. 2014. Towards sustainable agricultural stewardship: evolution and future directions of the permaculture concept. Environmental Values 23(1): 75-98.

Trenouth, L. Forthcoming. Tracing the contours of alternative food consumption in post-socialist Central and Eastern European countries. Working Paper.

Vaishar, A. 2010. Sustainable development of the Moravian countryside. Journal for Geography 5(1): 43-54.

Verdery, K. 1996. What was socialism, and what comes next? Princeton: Princeton University Press.

Veteto, J.R. and J. Lockyer. 2008. Environmental anthropology engaging permaculture: moving theory and practice toward sustainability. Culture and Agriculture 30(1-2): 47-58.

Veteto, J.R. and J. Lockyer. 2015. Applying anthropology to what? tactical/ethical decisions in an age of global neoliberal imperialism. Journal of Political Ecology 22: 357-367.

Walker, B. and D. Salt. 2006. Resilience thinking: sustaining ecosystems and people in a changing world. Washington D.C.: Island Press.

Wiersum, K.F. 2004. Forest gardens as an "intermediate" land-use system in the nature-culture continuum: characteristics and future potential. Agroforestry Systems 61: 123-134. 